\section{INVISIBLE NAVIGATION (OR IMPOSSIBLE?)}

Oguzhan Özcan, Design Lab., Koc University, 34450 Sariyer, Istanbul, Turkey E-mail: <oozcan@ku.edu.tr>.

Mary Lou O’Neil, Department of American Literature, Kadir Has, Cibali Istanbul, 34084 Turkey. E-mail: $<$ mloneil@khas.edu.tr>.

See <www.mitpressjournals.org/toc/leon/46/1> for supplemental files associated with this issue.

Submitted: 11 October 2011

\section{Abstract}

This article introduces an experimental artwork on moving mobile interfaces. It aims to answer the question: Is it possible to navigate a part of a large image composition, moving a smaller interface of a mobile device in a certain direction such as left and right, back and forth or up and down? The article then outlines the new concept of "Invisible (or impossible) Navigation" and discusses the output of artistic practices which address the "Labyrinth of Art".

\section{Moving the Image or You?}

On the mobile display, multi-touch technologies developments show that the artist can now design "a digital composition" which is navigated by the viewer, dragging it top or down, left or right with the hand. However, these new experiences may also provoke the artist to ask himself "how about moving the mobile device in real space, to explore and navigate over a large image?" In other words, can the artist think to change the structure: "move the device" rather then "drag with your hand", to see the other part of the image which is out of the range of the interface? Here, we discuss the possibility of creating an artistic work in such a problematic environment:
Research has provided technologies such as motion capture remote controls, hand tracking, eye tracking, biofeedback and neuro-feedback controls for human computer interaction. The new generation of game consoles like Nintendo Wii, Microsoft Xbox Kinect, and Sony PlayStation's Move, have already adopted some of these interfaces, not only to enhance the gaming experience, but also to provide media and information applications through the game consoles. Research shows that motion oriented devices provide an opportunity to develop moving media interfaces for more intuitive natural user interaction [1].

In moving media interfaces, the viewer can only navigate and make a part of the "ghost" media composition visible when he drags the special mobile display in limited directions and movements such as vertical, horizontal, wavy, etc. Although there is a rich potential in these technologies, novel design and interactive media design representations are not widely available for this type of media applications except for computer games. Studies in the field primarily focus on children and creating enjoyable learning activities for them [2]. If moving media interface can be developed more for artistic purposes, we believe that new visual representation techniques can be explored in interactive media art.

Working within the general perspective provided above, we believe that if we can use current and developing technologies in "innovative scenarios", we can find several different solutions to make "moving media interfaces" richer and more applicable to different con-

Fig. 1. This Structure is our Early Concept (@ 2010, Oguzhan Özcan)

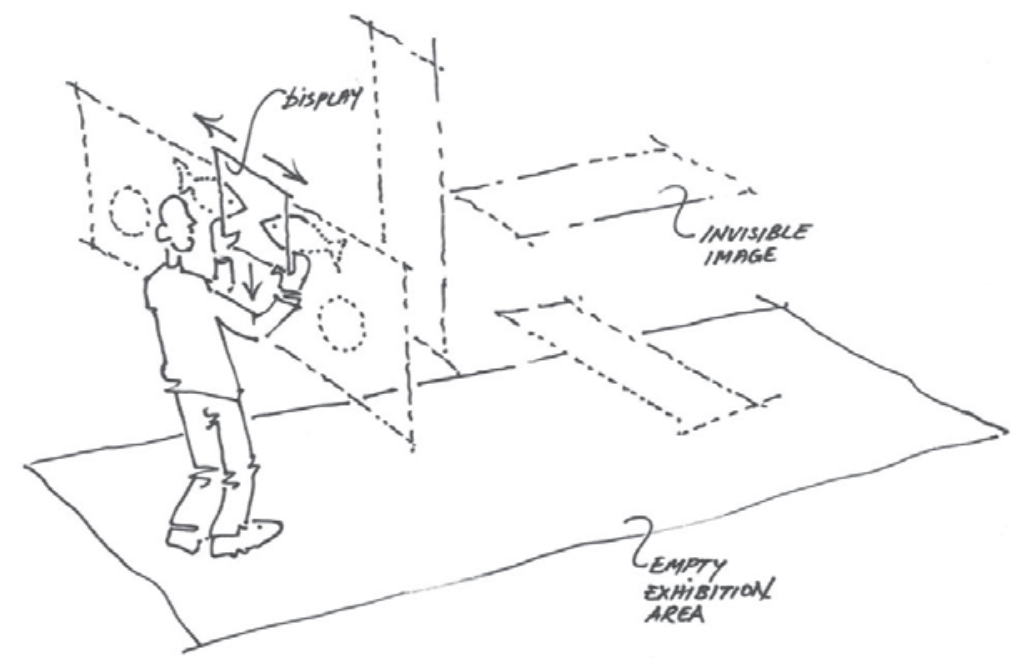

cepts. Working from this hypothesis, we focus on moving interfaces, based on moving mobile technologies and how to extend their usage in an "artistic way".

\section{Concept Current Artistic Research on the Topic}

Concerning our subject area, there are several future design scenarios on moving media interfaces that are not technically possible, as of yet. One of the best examples is a film that simulates holograms which appears when dragging the iPad [3].

Moving media interfaces should be related to an architectural space. Although there is no direct reference to this, there are a number of artistic examples like Damien Hirt's "Sliced Cow" [4][5] which provide the inspiration for a spatial interface idea in the movie titled "The Cell" [6]. Additionally, contemporary artists, such as David Hockney, have also experimented with artistic work on mobile devices [7]. Those works are based on drawings on multitouch devices which are set-up at an exhibition space.

For the 2-D interface manner, there is also a body of research. One of the important analyses is based on mixed interaction spaces. In this study, Hansen successfully accessed a part of the interface by moving the device left and right or top and down [8]. In the research, simple scenarios are also analyzed such as searching maps, playing games, etc.

At this time, we are aware of no study on "moving media interfaces" in the interactive media art field which focuses on limitations such as a 2-D vertical and horizontal space and "spatial multiple layers". Due to those restrictions, there are no graphical investigations which explore various "invisible shapes" connected to gestures, navigations, rhythms and motions to help the designer to understand how to create such a structure using moving media interfaces.

\section{Broader Implications of the "Invisible Navigation"}

Due to the fact that this is practice based research, we started practicing with a specified concept, to be able to then carry out experiments on more advanced concepts depending on our first findings:

The starting concept (Fig. 1) is a "ghost" (invisible) media form situated in an empty exhibition space which we have named "Invisible Navigation". In this structure, the viewer can only navigate and make a part of the "ghost" 
media composition visible. S/he can do this by dragging the special mobile display in limited directions and movements such as vertical, horizontal, wavy, etc. In this way, we intended to create a pan action in a $2 \mathrm{D}$ space interface in relation to the actual 3D motion of the device in $\mathrm{x}, \mathrm{y}, \mathrm{z}$ coordinates. With this limitation, the viewer can only discover a part of the media form, as when panning and viewing through the developed display system in a certain direction. In other words, the viewer can only imagine the complete media form by navigating piece by piece through the display system.

\section{Three Planes: Red Yellow Blue}

Given the conceptual framework outlined above, our artist created the following statement called 'Three Planes: Red Yellow Blue':

"A somewhat jestful take on Ellsworth Kelly's famous work of the 1960s, Three Planes is the old poem Beowulf 's three battles told a new through quirky metaphors, visual kennings, silly word-games and classical imagery.

"Wishing to push the viewer to participate rather than just looking, transforming the viewing-distance into a timeline came naturally: If you don't move, you don't get the whole picture. Working with only three images was a tougher choice, but the right one in trying to stay true to my original idea and making sure the demo didn't lose its focus.

"The three planes each represent one of the encounters with the antagonists; Grendel at Hrothgar's mead-hall, his grief-struck mother, and the dragon many years later. Time moves forward as you approach the wall."

Based on the artist's statement, we built a black stage, then our programmer set-up the coordination between the specified physical and virtual environment [9]. The three planes compositions, as layers, are horizontally fixed in that structure. A "curtain-by-light" is located on the position of each virtual plane in the exhibition area. Red-yellowblue lights identify each plane. In this way, we think that the feedback is easily understood with a logical connection to guide the viewer in our concept.

In this condition the viewer, at first, wore yellow rubber gloves, then took his iPad and directed himself to the "curtainby-light". By holding the iPad towards the lights, a part of the image appears on the screen of the iPad. The viewer could

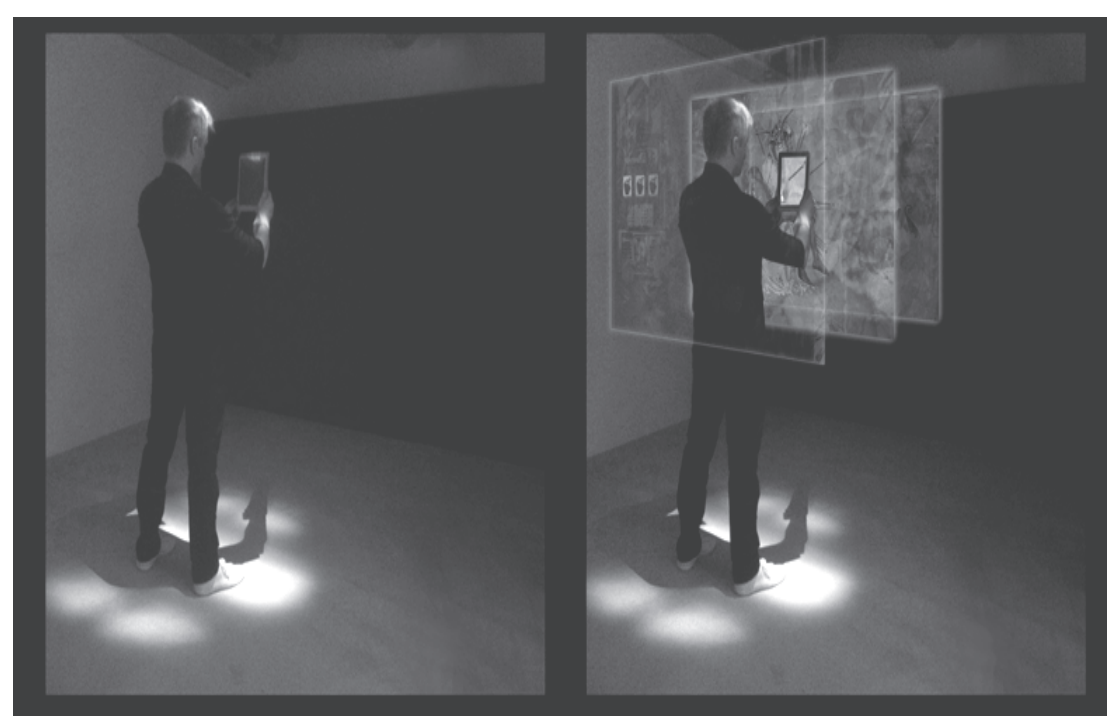

Fig. 2. The Invisible Navigation on the stage. Left: Actual Performance, Right: Invisible Part of the artwork. (C 2010, Oguzhan Özcan)

then move her iPad up and down, right or left to explore the whole image piece by piece. The viewer could also jump to another image located on another "curtain-by-light" by moving back or forth (Fig. 2).

In order to perform this task, the programmer decided to use a color-coding algorithm that tracks a specific color on video inputs. To recognize the location of the mobile device in a 3D environment, two separate cameras were used. Each camera can track the color in a 2D space and therefore the combination of results from the two cameras, results in a 3D location of the object. Color recognition is performed through OpenCV open source libraries.

The final software that we received fulfilled our expectations in this work. For the color recognition, we decided to use yellow rubber gloves

\section{Invisible or Impossible?}

There is no doubt that the concept of "invisible navigation" is a new way of looking through interface and rethinking our current usage of interactive media art. Feedback through "curtain-by light" could also be a new way to develop feedback in such systems. As interactive media artists, we should focus more on these issues which seem to have potential for innovative solutions in the near future.

Although it is important to get rid of cliché layouts in artistic design, using buttons, maps, arrows etc., it is sometimes difficult to navigate in such interactive systems. However, this project shows that the concept of "invisible (may be sometimes impossible!) navigation" itself is provocative enough to spawn further research explorations for new artistic representations and it may emerge as a new aspect of "Labyrinth of Art" as well.

\section{References and Notes}

1. Schou, T and Gardner, H.J A "Wii remote, a game engine, five sensor bars and a virtual reality theatre", In Proc.OzCHI,ACM Press (2007) pp. 231-234.

2. Doering, A., \& Veletsianos, "Multi-Scaffolding Learning Environment: An Analysis of Scaffolding and Its Impact on Cognitive Load and ProblemSolving Ability", Journal of Educational Computing Research 37, No. 2 (2007) pp.107-129.

3. Norhham B. (2010). "iPad Light Painting", $<$ http://www.dentsulondon.com/work/makingfuture-magic-ipad-light-painting $>$ accessed 3 October 2011.

4. Cristopher D, British Culture: An Introduction First Edition, (New York: Routledge, 1999) p. 173.

5. Damien H (1995). "Some Comfort Gained from the Acceptance of the Inherent Lies in Everything", $<$ http://www.gagosian.com/exhibitions/soho-199605-damien-hirst/\#/images/1> accessed 3 October 2011.

6. Sing T, The Cell, New Line Production Inch. USA (2000), film.

7. Hockney D (2010). "Fleurs Fraiches", Fondation Pierre Bergé-Yves Saint Laurent, Paris,

$<$ http://www.hockneypictures.com/past_exhibitions. php $>$ accessed 3 October 2011

8. Hansen R., Eriksson E., Olesen A.. "Movementbased interaction in camera spaces: a conceptual framework", Personal and Ubiquitous Computing 11, No:8, (2007) pp.621-632.

9. The artwork is funded by the Mälardalen University Artistic Development Grant. Concept and copyright holder: Oguzhan Özcan Artist: Martin Halm, Technical adviser: Afshin, Ameri E., Programmer: Stefan Bedetiktsson Hardware: Logitech Webcam C270, Netgear Wnr35001 Open Source Wlan-N Gigabit Router, Apple iPhone 4 and iPad 2, a windows desktop computer Software: XCode 4, Visual Studio 2010, VC++, OpenCV 2.1. 


\section{Thanks to Our Supporters}

Leonardo/ISAST is a nonprofit organization that serves the international arts community by documenting work at the intersection of the arts, sciences and technology and by encouraging and stimulating collaboration through its programs and activities. Donations and grants are integral to the future of Leonardo. Contact <isast@leonardo.info> or visit <http://leonardo.info> for more information.

Leonardo Codex

$(\$ 5,000$ and above $)$

College of Extended Learning,

San Francisco State University

Estate of Stephen Wilson

Roger Malina

The Malina Trust

Sonva Rapoport

Rockefeller Foundation

The San Francisco Art Institute

Al Smith

Darlene Tong

University of Texas at Dallas

\section{Sforza Monument}

(The Bronze Horse)

$(\$ 1,000$ to $\$ 4,999)$

Martin Anderson

Art Science Research Lab

Banff New Media Institute

Lisa Bornstein

CalArts

Caldas University Arts

and Humanities

Concordia University

DeMontfort University Institute for

Creative Technologies

Emily Carr University of Art \& Design

Donna Cox

Creative Disturbance

The Daniel Langlois Foundation

Char Davies

The Exploratorium

Penny Finnie

Steve Forestieri

Gregory Harper

John Hearst

Intel Corporation

LABoral Centro de Arte y Creacion Industria

The LEF Foundation

Alan Malina

Marjorie Malina

Jacques Mandelbrojt

Christine Maxwell-Malina

Ontario College of Art \& Design University

Sheila Pinkel

Michael Punt

Rhode Island School of Design

Itsuo Sakane

School of the Art Institute of Chicago

Scottsdale Center for the Performing Arts

Martin Segal

SFSU International Center for the Arts

Sonia Sheridan

Srishti School of Art, Design and Technology

swissnex San Francisco

SymbioticA

Marcia Tanner

Makepeace Tsao

UCLA Art / Sci Center

UC Santa Barbara, Media Arts and Technology

Program

UC Santa Cruz, Digital Arts and

New Media Dept.

Universidad Autonoma de Occidente,

Engineering Department

Universidad de San Buenaventura,

Multimedia Engineering Program

Universidade de Caldas

Universidade do Minho

University of Calabria Evolutionary Systems

Group

University of Denver School of Art

and Art History
University of Évora, CHAIA

University of Florida Digital Worlds Institute

University of Illinois

eDREAM Institute

University of Leiden

University of Plymouth, U.K

University of Washington DXARTS

UTS Creativity and Cognition Studios

ZKM | Center for Art and Media

$\begin{array}{ll}\text { La Gioconda (Mona Lisa) } & \text { Stephen Wilson } \\ \text { (\$500 to \$999) } & \text { Gary Zellerbach }\end{array}$

Roy Ascott

Lars Ole Belhage

Martha Blassnigg

Anna Campbell Bliss

Leif Brush

James D. Burke

Richard Clar

Una Dora Copley

Bryony Dalefield

Michele Emmer

William Fawley

Arana Greenberg

Michael Joaquin Grey

Dene Grigar

Rosemary Jackson

Larry Larson

Lynn Hershman Leeson

Guy Levrier

Isabel Maxwell

Merrill Lynch Foundation

Emanuel Nadler

Nessim \& Associates

Sam Okoshken

Steve Oscherwitz

Trudy Reagan

David Rosenboom

Jack Sarfatti

Joel Silverman

Christian Simm

Tami Spector

Meredith Tromble

\section{Flying Machine}

(\$250 to \$499)

Loren Basch

Ray Bradbury

Bettina Brendel

Shawn Brixey

David Carrier

Eva Craig

Holly Crawford

Eugene Epstein

Lawrence Fane

Herbert Franke

Doreen Gatland

Pamela Grant-Ryan

Oliver Grau

Linda Dalrymple Henderson

Robert Hill

Curtis Karnow

Melinda Klayman

Kathleen Laziza

Thomas Mercer

Gianluca Mura

Frieder Nake

Barbara Nessim

Jack Ox

Ed Payne and Liss Fain

Nancy Perloff

Frank Popper

Harry Rand

Beverly Reiser
Mark Resch

Eric Roll

Edward Shanken

Leonard Shlain

Jesse Tischler

Joan Truckenbrod

Kelvin Tsao

Jonathan Willard

Barbara Lee Williams

Richard A. Wilson

\section{Angel}

(\$249 and under)

Anonymous, Aaron Alpar, Charles Ames, Craig Anderson, Art Science Collaborations

Inc. (ASCI), Yasuhiro Asoo, Bret Battey, Marc Battier, Mark and Lauren Beam, Patricia Bentson, Timothy Binkley, The Birse Family,

Marc Böhlen, Deborah Branton, Robert A.

Brown, Ronald Brown, Willi Bruns, Annick

Bureaud, James Burke, David Carter, Rosa Casarez-Levison, Webster Cash, Katherine

Casida, Joel Chadabe, Alison Chaiken, John

Chowning, Richard Clar, Computer Art

Studio/Gunter Schulz, Ivo Cristante, Elizabeth

Crumley, Mary \& Michael Cunningam, Danish

Film Festival, Bob Davis, Derrick de Kerckhove,

Goery Delacote, Lily Diaz, Agnes Denes, Emma

Lou Diemer, Steve Dietz, Augus Dorbie, Hubert

Duprat, Elmer Duncan, Ann Elias, Sherban

Epure, Theodosia Ferguson, John Fobes, Tim

Fox, Alan \& Mickey Friedman, Ryozo Fujii,

Kai-hung Fung, David Gamper, Jonathan \&

Donna R. Gennick, George Gessert, Ken

Goldberg, Yusef Grillo, Karen Guzak, Craig

Harris, Isabel Hayden, Margaret Hermann,

Doris Herrick, Estate of Dick Higgins, Kathy

High, Anthony Hill, Toshiyuki Hiruma, Gerald

Holton, Hungarian University of Crafts \&

Design, Amy Ione, Susan Joyce, Raymond

Jurgens, Eduardo Kac, Robert Kadesch,

Marshall Kaplan, Ken Knowlton, Zdenek

Kocib, Kenji Kohiyama, Thomas Kostusiak,

Kathleen Laziza, Levi Family Foundation,

Frederick Loomis, Carl Machover, James

Maher, William Marchant, Delle Maxwell,

Elliot Mazer, Kevin Meehan, Minneapolis

College of Art \& Design, Mit Mitropoulos,

Moët Hennessy-Louis Vuitton, Jason Monberg,

Roger Mulkey, Geetha Narayanan, Alex

Nicoloff, Greg Niemeyer, Hiroshi Ninomiya,

Elaine Petschek, Anne Brooks Pfister, Glenn

R. Phillips, Victor A. Pickett, Otto Piene, Ann

Pizzorusso, Herbert \& Joan Webster Price,

Patric Prince, Wolf Rainer, Peter Richards,

Ron Rocco, Peter Rudolfi, David M. Russell,

Mr. and Mrs. Robert Russett, Colin Sanderson,

Piero Scaruffi, Patricia Search, Allan Shields,

Gregory C. Shubin, Joel Slayton, John Slorp,

Avril Sokolov, Kirill Sokolov, Christa Sommerer,

Rejane Spitz, Anait Stephens, Robert Strizich,

The Sun Microsystems Foundation, Inc.

Robin and Barbara Tchartoff, Tamiko Thiel,

Rodrigo B. Toledo, Heinz Trauboth, Mark

Tribe, Karen Tsao, Roman Verostko, Alexandre

Vitkine, Annette Weitraub, Natalie \& Mark

Whitson, Alan Thompson \& Sharon A.

Widmayer, Ioannis Yessios, Robert

Zimmerman 